\title{
Estimation of the New Gas-cap to the Performance of the Reservoir of the Oil Field Libwa, Offshore of the Democratic Republic of Congo
}

\author{
Joel Kabesa Kilungu ${ }^{1}$, Dominique Wetshondo Osomba ${ }^{2}$, El-Richard Molodi Empi ${ }^{1}$, \\ Shams Diambu Mbudi ${ }^{1}$, Romulus Mawa Tuzingila ${ }^{1}$, Link Bukasa Muamba ${ }^{1}$, \\ Junior Mbambo Bokitshi ${ }^{1}$ \\ ${ }^{1}$ Department of Exploration-Production, Faculty of Oil, Gas and New Energies, University of Kinshasa, Kinshasa, Democratic Republic of \\ Congo \\ ${ }^{2}$ Department of Geosciences, Faculty of Science, University of Kinshasa, Kinshasa, Democratic Republic of Congo
}

\section{Email address:}

joelinekabema1@gmail.com(J.K.Kilungu),dwosomba2012@yahoo.fr(D.W. Osomba), richardmolodi@gmail.com (E1-R.M.Empi), shamsdiambu7@gmail.com(S. D. Mbudi),romulus.mawa@gmail.com (R.M. Tuzingila), lincolnbukasa@gmail.com(L.B. Muamba), juniormbambo1@gmail.com(J.M. Bokitshi)

\section{To cite this article:}

Joel Kabesa Kilungu, Dominique Wetshondo Osomba, El-Richard Molodi Empi, Shams Diambu Mbudi, Romulus Mawa Tuzingila, Link Bukasa Muamba, Junior Mbambo Bokitshi. Estimation of the New Gas-cap to the Performance of the Reservoir of the Oil Field Libwa, Offshore of the Democratic Republic of Congo. International Journal of Oil, Gas and Coal Engineering. Special Issue: Advances in Enhanced Oil Recovery for Conventional and Unconventional Reservoirs. Vol. 7, No. 6, 2019, pp. 109-117. doi: 10.11648/j.ogce.20190706.11

Received: September 16, 2019; Accepted: October 29, 2019; Published: November 20, 2019

\begin{abstract}
The quantity of hydrocarbons initially in place and the technique of exploitation employed in the reservoir determine the period of an oilfield. But the quantity of hydrocarbons in a reservoir defines as a preliminary the type of mechanism drainage which governs the pressure of the oilfield. And this pressure is the key parameter of the oil production. Thus, the mechanism of drainage is a motive element which shows the performance of an oil reservoir during the production. During the oil production in the Upper Pinda reservoir of the Libwa field, the mechanism of drainage used was that of gases in solution. It was noticed that during the production, an abrupt drop of the pressure of 2670 psia with 1567 psia and a cumulated production of oil of $239805 \mathrm{Stb}$ at the end of the year 2018. However, certain studies undertaken in this field revealed the presence of a gas cap which could compensate for the mechanism with dissolved gas but which seemed to be ineffective during the drop pressure. Thus through our study, we put in evidence the existing quantity of gas in the primary gas cap which are worth 1.09414 MMscf under the basic conditions and with the factor of the primary gas cap (m) with 0.0018 who is scarcely and the new gas cap which is created starting from the addition of a quantity of dissolved gas released during the production of which the quantity of this gas is estimated at 1.86329 MMscf under the basic conditions and, the new factor of the gas cap (m) is worth 0.0059 and the value of this new factor of the gas cap $(\mathrm{m})$ is almost null too. Taking into consideration these result, it is shown that this new gas cap will be always ineffective with the performance of the reservoir. On this it is necessary that the factor of the gas cap reaches a value at least equal to 10 to completely replace the mechanism with gas dissolved in the Upper Pinda reservoir in the Libwa field.
\end{abstract}

Keywords: Mechanism of Drainage, Material Balance Equation, Oil-Gas Ratio, Drop Pressure, Gas-Cap Factor

\section{Introduction}

The fluids contained in an oilfield not yet exploited, have a rather significant pressure and are always susceptible to slacken for the period of production. The solid matrix of the porous rock containing these fluids is also susceptible to dilate, if the pressure of the fluids contained in the pores decreases. This capacity of expansion of the fluids and the rock matrix resulting from the drop pressure of the fluids of the oilfield produced on 
the surface is the principal driving agent of the natural drainage commonly called mechanism of production. These mechanisms lead to the production known as primary and the calculation of the index of drainage, definite like the expansion of a mechanism on the production of oil and its associated gas. The performance of the oil reservoir is determined by the type of the mechanism of drainage available to push oil to the purlieus of the well. Moreover, the mechanism of drainage defining the performance of the reservoir is a function of the rate of recovery, of decline of pressure, his oil-gas ratio and its production of water. There are several mechanisms of drainage, but the principal mechanisms are the mechanism of drainage by depletion and the mechanism of drainage by water. In a reservoir where the mechanism of drainage is the depletion, energy comes by the expansion from the fluids from the reservoir and dilation from porous space caused by fromt the drop pressure. It is necessary to announce that the mechanism of drainage by depletion includes/understands two modes of which the mechanism of drainage by dissolved gas and gas cap. The natural depletion is controlled by the material balance equation which is a basic tool permiting it possible to verify the uniformity of the data of production, coherence between the geological evaluation and the behavior of the reservoir, to understand the behavior of the reservoir, to envisage a future program of complementary development, and calculates forecasts of production [1]. The Libwa field which is the subject of our study is located at $7 \mathrm{~km}$ of the coast of the Democratic Republic of Congo more precisely localised to the following geographical coordinates $12^{\circ} 15^{\prime} 42.2631^{\prime \prime}$ Est and $12^{\circ} 15^{\prime} 40.2^{\prime \prime}$ of longitude East and 556’32.8916" and 5'56’31.6” of Southern latitude and the depth of water is with approximately 6meters (Figure 1). The field produces oil normally and gas starting from the calcareous reservoir of Upper Pinda and it is a reservoir with a gas cap. This last is known as an impermeable carbonated reservoir having permeabilities which oscillate between 0.04 $\mathrm{mDarcy}$ and $19 \mathrm{mD}$. With regard to the geology of the field, the development of the Libwa Field to date is largely focused on its Northern portion. It is predicted that significant not yet developed reserves exist in its Southern part, however, of knowledge on the quality of the reservoir in this zone remain limited. To date, 16 wells were drilled in this field and 11 wells only produced in the infrastructures of the Offshore oil rig. But, one could observe that with the mechanism of drainage to dissolved gas, a fall of pressure within the Upper Pinda reservoir in the Libwa field of 2670 psia than 1567 psia which conduct to a very partiality production of the field in 2018 [2]. According to the geological investigations and geophysics carried out in this field, it was shown that this reservoir with its upper part has a gas cap which can be useful like mechanism of drainage with gas cap compared to its volume or by injection of gas with the top of the reservoir. Whereas for the reservoir producing by gas dissolved drainage, while the drop pressure below the pressure at the point of bubble, of the bubbles point are released in the microscopic pores [3]. As regards this quantity of released gases; a part is produced on the surface and another migrates towards the top of the reservoir to improve volume of existing gas cap, which leads to a volume of gas cap known as secondary of the reservoir and creates also a new contact gas-oil.

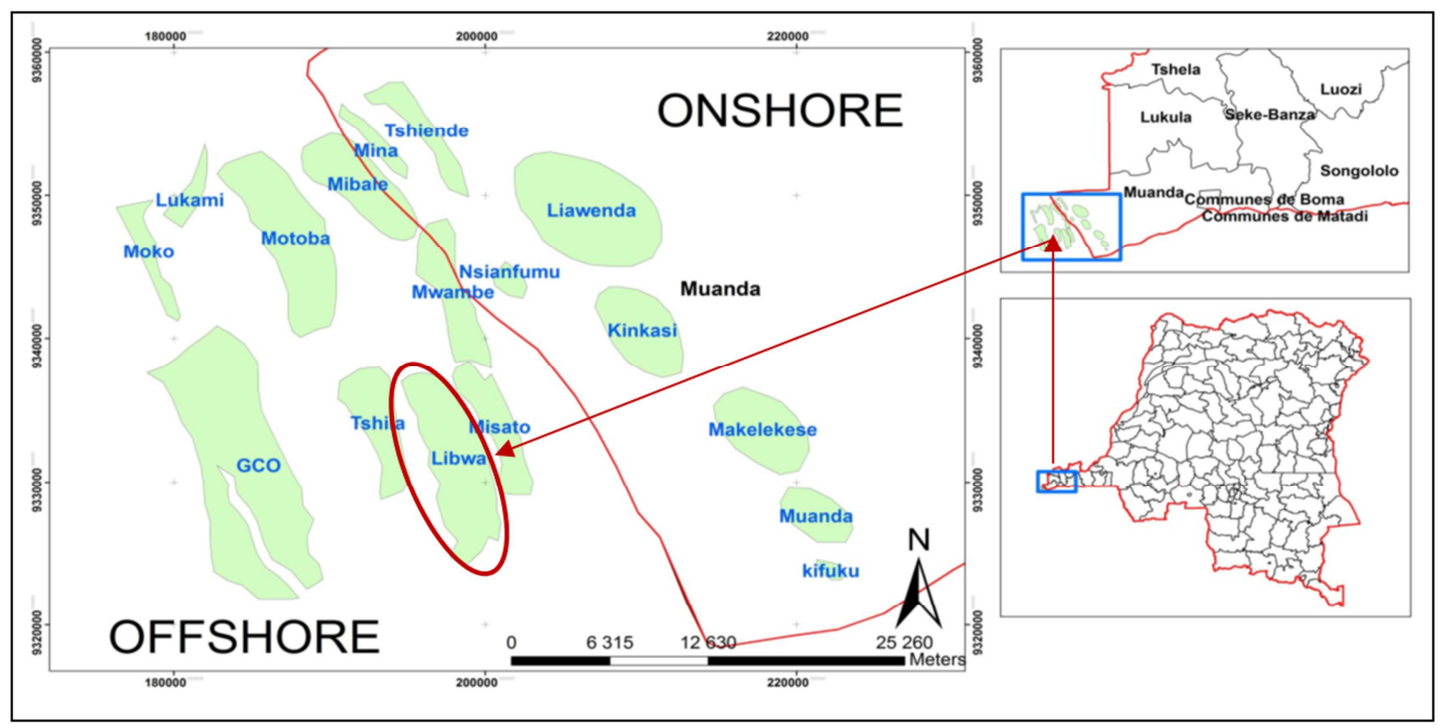

Figure 1. Location of Libwa field in the coastal basin of the Democratic Republic of Congo.

\section{Material and Method}

\subsection{Material}

We used a laptop containing: Word, Excel, Arc-Gis, Surfer.

\subsection{Data Collection}

The identification and the localization precise of the trap with oil are one of the essential spots [4]. This geometric form called trap exit of the data the surface-depths makes it possible to identify the various contacts between the fluids of the reservoir i.e. the contact oil-gas and oil-water according to their depth [5]. As specifies as can be study PVT, it will have significance only if it is carried out on a sample really representative of the fluid of oilfield. On this, information being used to determine the new volume of the gas cap and 
the contact of surface between oil and gas results from:

a. petrophysic data of parameters of three wells Libwa-12, Libwa-2, Libwa-1 for the plotting of surfaces of the various isobaths to the top of the Upper Pinda reservoir;

b. data of Pressure, Volume and Temperature of the fluids of the field Libwa for the determination of the volume gas primary of the gas cap;c. data of production of the Libwa field as from the period of 1990 to 2018 to determine the quantity of remaining oil and the factor of the current gas cap.

\subsection{Method}

There are two very different groups of methods which make it possible to calculate the reserve places in an oilfield; it is about the volumetric method and the dynamic method. The method used for the estimate of the new gas cap is the dynamic method in general and that of the material balance in particular; because the material balance is interested only in displacements of the fluids thus where there is a difference in pressure, it makes it possible to give the dynamic quantities, this last method is applicable only when the oilfield already produced for a certain time ( 1 to 2 years minimum) and it is used to thus control the values obtained by the volumetric methods it is based on the historical data of production of the field. We will also be used for ourselves of the method of cubature known as planimetric to find the depth of contact between gas and oil. This method makes it possible to plot the curves of the surface of the top and the bottom according to coast $\mathrm{Z}$ (depth) and determines the surface of contacts water-oil and oil-gas.

\section{Results and Interpretations}

\subsection{Parameters Petrophysic of the Upper Pinda Tank Reservoir}

The precise knowledge of the petrophysic properties of a reservoir is required for the calculation of accumulations and hydrocarbon reserves in place, of the efficient development of the field and to predict the future performance of the reservoir. These parameters result from the Libwa-1, -2 and 12 wells of the Upper Pinda reservoir.

\subsubsection{Petrophysic Data Processing of the Libwa-1 Well}

The vertical well Libwa-1 drilled in June 1981 was the all first well to be drilled in the Libwa field in order to determine the delimitation of the oilfield. And in June 2002, this well has sustained additional perforations. In table 1, we present information collected at the Libwa-1 well.

Note: UP_ 3 and UP_2 are lithofacies which subdivide the Upper Pinda reservoir. UP_ 2 is an environment depositional continental upland and UP_3 is a skeletal environment depositional high bottom complex.

Table 1. Results of petrophysics of Libwa-1 well.

\begin{tabular}{|c|c|c|c|c|c|c|c|c|c|}
\hline Zone & Top & Bottom & Gross & Net & $\mathrm{N} / \mathrm{T}$ & Porosity & Ave Sw & Ave perm & $\mathbf{K h}$ \\
\hline Name & Feet & Feet & Feet & Feet & Ratio & Ratio & Ratio & $\mathrm{mD}$ & mD.ft \\
\hline UP 3 & 5163 & 5363 & 200 & 154 & - & 0.175 & 0.20 & - & - \\
\hline UP_2 & 5363 & 5570 & 207 & 30 & - & 0.158 & 0.25 & - & - \\
\hline
\end{tabular}

\subsubsection{Petrophysic Data Processing of the Libwa-2 Well}

The Libwa-2 well was drilled in August 1981 in the West of the Libwa-1 well and revealed that its impregnated zone of hydrocarbons is almost made of oil but with a thickness zone with gas subjacent known as gas cap of 14 feet (Table 2 ).

Table 2. Results petrophysic Libwa-2 well.

\begin{tabular}{|c|c|c|c|c|c|c|c|c|c|}
\hline Zone & Top & Bottom & Gross & Net & $\mathrm{N} / \mathrm{T}$ & Porosity & Ave sw & Ave perm & $\mathbf{K h}$ \\
\hline Name & Feet & Feet & Feet & Feet & Ratio & Ratio & Ratio & $\mathbf{m D}$ & mD.ft \\
\hline UP_3 & 5456 & 5484 & 28 & 14 & - & 0.168 & 0.30 & - & - \\
\hline UP 2 & 5484 & - & 341 & 277 & - & 0.18 & 0.265 & - & - \\
\hline
\end{tabular}

\subsubsection{Petrophysic Data Processing of the Libwa-12 Well}

Libwa-12 is a well multilateral drilled in 2013.

Petrophysic interpretation has exposed a reservoir of very quality (Table 3 ).

Table 3. Results petrophysic Libwa-12 well.

\begin{tabular}{|c|c|c|c|c|c|c|c|c|c|c|}
\hline \multirow{2}{*}{ Lateral } & Zone & Top & Bottom & Gross & Net & $\mathbf{N} / \mathbf{G}$ & Av Phi & Ave Sw & Ave perm & Kh \\
\hline & Name & Feet & Feet & Feet & Feet & Ratio & Ratio & Ratio & $\mathbf{m D}$ & mD.ft \\
\hline \multirow{3}{*}{ Lat-2 } & Up-3 & 6550 & 10679 & 4029 & 3769 & 0.94 & 0.19 & 0.22 & 1.72 & 6490 \\
\hline & Up-2 & 10579 & 11207 & 629 & 152 & 0.24 & 0.19 & 0.13 & 1.76 & 267 \\
\hline & All & 6550 & 11207 & 4657 & 3921 & 0.84 & 0.19 & 0.21 & 1.72 & 6757 \\
\hline \multirow{3}{*}{ Lat-1 } & Up-3 & 7037 & 9844 & 2807 & 2804 & 1.00 & 0.19 & 0.24 & 1.43 & 4012 \\
\hline & Up-2 & 9844 & 11525 & 1682 & 1397 & 0.83 & 0.18 & 0.25 & 1.30 & 1815 \\
\hline & All & 7037 & 11525 & 4489 & 4200 & 0.94 & 0.19 & 0.25 & 1.39 & 5830 \\
\hline TOTAL & & & & 9146 & 8121 & 0.89 & 0.19 & 0.23 & 1.55 & 12587 \\
\hline
\end{tabular}


The results of the drill stream test (DST) realized in this field revealed a good quality of cementing and the extreme precaution to take during the operations of stimulation in order to avoid fracturing in the gas cap. By combining the petrophysic data drawn starting from the various wells from the Libwa field, one finds the chart of the isobaths delimiting the contacts between the fluids of the Upper Pinda reservoir (Figure 2). An initial pressure of 2670 psia of the Upper Pinda reservoir was given with the initial contact gas-oil (GOC) with the underwater vertical depth of $5400 \mathrm{ft}$ and $5665 \mathrm{ft}$ with the initial contact oil-water (OWC) in the Libwa field.
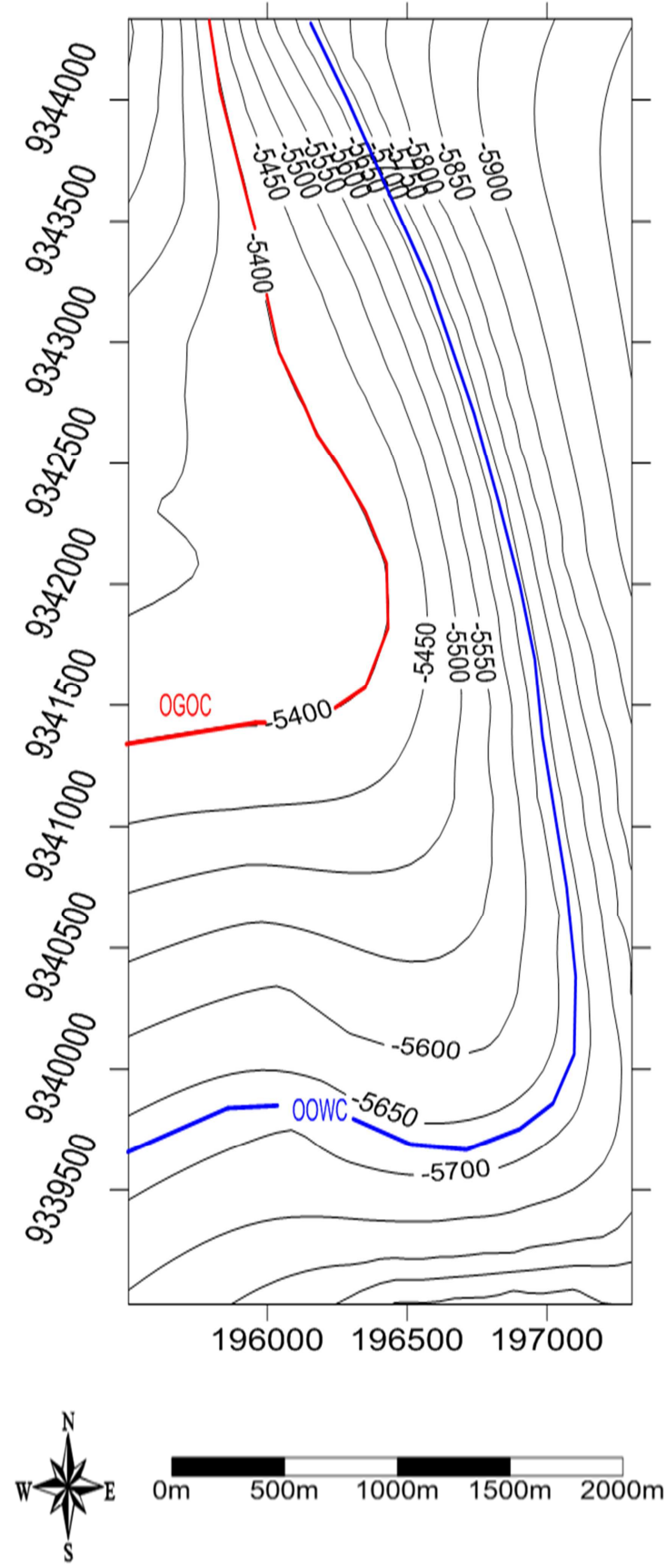

Figure 2. Chart of the isobaths delimiting the contacts between the fluids of the Upper Pinda reservoir.

\subsection{Calculations of the Parameters of PVT of the Upper Pinda Reservoir}

The calculation of parameters PVT of an oil reservoir do allow to make the evaluation of hydrocarbons in place, to analyze the composition of the fluids, to understand the behavior of the phases during the production and the digital simulation on the scale of the field thus it makes it possible to determine the physical and chemical characteristics fluids of the reservoir in order to predict its behavior when the pressure and the temperature change. It is necessary to announce that during the oil production, the temperature within the reservoir does not vary. The petrophysic properties of the Upper Pinda reservoir of the Libwa field and the fluids there contained are given in table 4 :

Table 4. Properties PVT of the Libwa field.

\begin{tabular}{|c|c|c|}
\hline & $\begin{array}{l}\text { PVT already in } \\
\text { practice in the oil } \\
\text { bloc of the D R } \\
\text { Congo }\end{array}$ & $\begin{array}{l}\text { PVT from the } \\
\text { analysis of the } \\
\text { libwa-3 well tests } \\
\text { carried out in } 1989 .\end{array}$ \\
\hline Reservoir Temperature & $169^{\circ} \mathrm{F}$ & $169^{\circ} \mathrm{F}$ \\
\hline Gravity of the oil $\left(\gamma_{o}\right)$ & $33.8^{\circ} \mathrm{API}$ & $32.1^{\circ} \mathrm{API}$ \\
\hline Specific gravity of the gas $\left(\gamma_{q}\right)$ & 0.82 & 0.82 \\
\hline $\begin{array}{l}\text { Gas-oil Ratio }(\mathrm{GOR}) \text { in } \\
\text { solution }\left(\mathrm{R}_{\mathrm{S}}\right)\end{array}$ & $550 \mathrm{Scf} / \mathrm{Stb}$ & $470 \mathrm{Scf} / \mathrm{Stb}$ \\
\hline $\begin{array}{l}\text { Bubble point pressure }(\mathrm{Pb}) \text { at } \\
\text { reservoir temperature }\end{array}$ & 2583 psia & 2540 psia \\
\hline $\begin{array}{l}\text { Oil formation volume factor } \\
\text { (Bo) and Oil formation volume } \\
\text { factor Initial (Boi) }\end{array}$ & $\begin{array}{l}1.31 \text { reference } \\
\text { barrel }(\mathrm{rb}) / \mathrm{Stb}\end{array}$ & $1.254 \mathrm{rb} / \mathrm{Stb}$ \\
\hline Viscosity of the oil at $\mathrm{Pb}\left(\mu_{\mathrm{ob}}\right)$ & $1.38 \mathrm{Cp}$ & $1.37 \mathrm{Cp}$ \\
\hline $\begin{array}{l}\text { No hydrocarbon components } \\
\text { (impurities) }\end{array}$ & $\begin{array}{l}\mathrm{H}_{2} \mathrm{~S}=0 \% ; \mathrm{CO}_{2}= \\
0 \% ; \mathrm{N}_{2}=0 \%\end{array}$ & \\
\hline Water salinity & $\begin{array}{l}25,000 \text { part per } \\
\text { million (ppm) }\end{array}$ & \\
\hline Gas deviation factor $(Z)$ & $0.85 \mathrm{psi}^{-1}$ & \\
\hline Porosity $(\phi)$ & $16.7 \%$ & \\
\hline Gas Compressibility (Cg) & $0.85 \mathrm{psi}^{-1}$ & \\
\hline Permeability & $3.4 \mathrm{Md}$ & \\
\hline Stock tank oil initially in place & 491 MMStb & \\
\hline Standard pressure & 14.7 psia & \\
\hline Standard temperature & $60^{\circ} \mathrm{F}$ & \\
\hline
\end{tabular}

It is known that above the critical point, the phases of liquid and vapor are impossible to distinguish them and the physical interface between them disappears [6]. At the critical point, the corresponding pressure and the temperature are called the critical pressure $\left(\mathrm{P}_{\mathrm{c}}\right)$ and the critical temperature $\left(\mathrm{T}_{\mathrm{c}}\right)$ of the mixture [3].

i. Critical Pressure of Upper Pinda Reservoir in the Libwa Field

The pressure regime in the hydrocarbon columns are commanded by the water pressure reigning in the vicinity of the reservoir. In the ideal case, the water pressure $\left(\mathrm{P}_{\mathrm{w}}\right)$ to a given depth is by the equation [7]:

$$
P_{w}=\frac{(d p)}{(d D)} * \mathrm{D}+14.7
$$

with $\mathrm{D}$ : depth in $\mathrm{ft}$; $\mathrm{dD}$ : différence in depth; dp: différence in pressure. The pressure regimes of hydrocarbon are different because of the densities of oil and of gases which are inferior 
than that of water and consequently, the gradients of pressure are too small. Thus, for the reservoir containing oil and a gascap, one has values of the pressure gradient as follows [8]:

$$
\begin{gathered}
\left(\frac{d p}{d D}\right)_{\text {water }}=0.45 \frac{p s i}{f t} \\
\left(\frac{d p}{d D}\right)_{o i l}=0.35 \frac{p s i}{f t} \\
\left(\frac{d p}{d D}\right)_{g a z}=0.08 \frac{p s i}{f t} .
\end{gathered}
$$

In the case of our study, the depth of water-oil contact (OWC) in the reservoir is $5665 \mathrm{ft}$ and water is salted, by replacing each parameter of the equation (1) by its value, the water pressure is worth 2563.95 psia. The linear equation for the oil pressure above the surface of contact water-oil is given by this relation

$$
P_{o}=\frac{(d p)}{(d D)} * \mathrm{D}+\mathrm{C}
$$

with $\mathrm{C}$ is a constant which is positive if water exceeds with the pressure and negative if it is under pressurized. By replacing the value of $\left(\frac{d p}{d D}\right)_{\text {oil }}$ with the equation (2), one has:

$$
P_{o}=0.35 * \mathrm{D}+\mathrm{C}
$$

It is necessary to announce that in contact oil-water beyond $5500 \mathrm{ft}$, the oil pressure and water pressure must be equal differently a static interface would not exist. What gives us: $P_{o}=P_{w}=2563.95$ psia, one finds $\mathrm{C}$ starting from the equation (3), the value of $\mathrm{C}$ is 581,2 psia which is the critical pressure in the center of gravity on the surface of contact water-oil. Therefore, for the oil pressure above the surface of contact water-oil is, according to the equation (4):

$$
P_{o}=0.35 * \mathrm{D}+581.2
$$

Let us replace D by its value, then: $P_{o}=2563.95$ which is the same one as that $P_{w}$. Lastly, for the pressure above the surface of contact gas-oil, the pressure being hydrostatic (the same in all the directions) is thus the same in the two fluids on their surface of contact thus $P_{o}=P_{g}$. One will be the following equation:

$$
P_{g}=\left(\frac{d p}{d D}\right)_{g a s} * \mathrm{D}+\mathrm{C}
$$

by replacing the values of each parameter in the equation (8) by considering the value of the pressure gradient in cas of the gas, $\mathrm{D}=5400 \mathrm{ft}$ and $P_{g}=2563.95$ psia; one has: $\mathrm{C}=2563.95$ $0.08 * 5400 \rightarrow \mathrm{C}=2131.95$ psia which is the critical pressure in the center of gravity GOC. One notices that the pressure found between the various contacts of fluids who is of 2563.95 psia borders that of the pressure of the bubble point (see table 3). The current pressure of the reservoir which is of 1567 psia is strictly inferior than the critical pressure; that means quite simply that there is not or very weak contribution of dissolved gases.

\section{ii. Critical Temperature of Upper Pinda Reservoir in the}

\section{Libwa Field}

The temperature is an indication of the kinetic energy of the molecules. It is a physical measurement of the average kinetic energy of the molecules. The kinetic energy increases while heat is added. This increase in kinetic energy causes an increase in the movement of the molecules which also has like consequence the displacement of the molecules further separately. When the critical temperature is equal to the temperature of the reservoir, the curve of $(\mathrm{P}, \mathrm{T})$ passes by the critical point. The determination of temperature $\left(\mathrm{T}_{\mathrm{GOC}}\right)$, to the surface of contact oil-gas (GOC), according to the mode of temperature is given in the form of this equation according to our field of study:

$$
\mathrm{T}_{\mathrm{GOC}}=\frac{(\mathrm{dT})}{(\mathrm{dD})} * \mathrm{D}+(\mathrm{T}+60)^{\circ} \mathrm{F}
$$

In the Pinda reservoir, the variation in temperature $\frac{(d T)}{(d D)}=\frac{1.65}{100}$; the depth $\mathrm{D}$ of the surface of contact oil-gas is with $5400 \mathrm{ft}$ and the temperature of the reservoir is $169^{\circ} \mathrm{F}$ (see table 3 ), by replacing the values of each parameter in the equation (6), one has $\mathrm{T}_{\mathrm{GOC}}$ which is equal $318.1^{\circ} \mathrm{F}$. This temperature is regarded as the critical temperature in the centre of gravity between oil-gas and will vary with the new oil-gas contact.And also, the temperature of the oilfield is inferior than the critical temperature of the mixture which is contained there.

iii. Determination of the Parameters of Gas Expansion $\left(E_{g}\right)$

The expansion of the fluids in an oil reservoir depends on the pressure which results from the type of mechanism of drainage in place. The variation (depletion in general) of this pressure leads to an expansion of the fluids of the reservoir according to their density. If there are initially a liquid phase and a phase vapor hydrocarbons balances some: oil with gas dome (gas cap), part of gas released during the production can join the gas-cap [5]. On this, the equation of the gas (E) expansion is inversely proportional to the gas formation volume factor $\left(\mathrm{B}_{\mathrm{g}}\right)[7,9]$ :

$$
B_{g}=\frac{P_{s c}}{P} \frac{T}{T_{s c}} \frac{Z}{Z_{s c}}=0.00504 \frac{z T}{P}
$$

expressed in $\mathrm{rb} / \mathrm{scf}$ and

$$
E=\frac{1}{B_{g}}=198.32 \frac{P}{z T}
$$

expressed in $\mathrm{scf} / \mathrm{rb}$ or otherwise, $\mathrm{E}=\frac{1}{5,615 B_{g}}$ expressed in scf/rcf.

According to our reservoir, the initial gas expansion $\left(\mathrm{E}_{\mathrm{i}}\right)$ is given with the initial pressure of the reservoir (2670 psia) and $\mathrm{Z}$ (table 5) which gave the gas formation volume factor initial $\left(\mathrm{B}_{\mathrm{gi}}\right)$ to $0.00101 \mathrm{rb} / \mathrm{scf}$; by replacing this value in the equation (8), there is $E_{i}$ which is worth $990.1 \mathrm{scf} / \mathrm{rb}$. According to the various pressures of the Upper Pinda reservoir and various values of the deviation factor $(Z)$ found starting from the mathematical expression of the chart of Standing and Katz 
developed by Hall and Yarborough gave the results of the expansion factor (E) following (Table 5):

Table 5. Results of the factor of the expansion (E) according to the pressures of the Upper Pinda reservoir in the Libwa field.

\begin{tabular}{lllll}
\hline Pression & $\mathbf{Z}$ & $\mathbf{B g}$ & $\mathbf{E}=\mathbf{1 9 8 . 3 2} \frac{\boldsymbol{P}}{\mathbf{z T}}$ & $\mathbf{E}=\frac{\mathbf{1}}{\mathbf{5 , 6 1 5 B} \boldsymbol{g}}$ \\
\hline 2670 & 0.85 & 0.00101 & 990.1 & 176.3 \\
2583 & 0.84 & 0.00103 & 970.9 & 172.9 \\
2500 & 0.8395 & 0.00106 & 943.4 & 168 \\
2300 & 0.8395 & 0.00106 & 943.4 & 168 \\
2100 & 0.8395 & 0.00116 & 862.1 & 153.5 \\
1900 & 0.842 & 0.00127 & 787.4 & 140.2 \\
1700 & 0.8472 & 0.00141 & 709.2 & 126.3 \\
1500 & 0.855 & 0.00159 & 628.9 & 112 \\
1300 & 0.8653 & 0.00183 & 546.4 & 97.3 \\
1100 & 0.8779 & 0.00214 & 467.3 & 83.2 \\
900 & 0.8925 & 0.00257 & 389.1 & 69.3 \\
700 & 0.9091 & 0.0032 & 312.5 & 55.7 \\
\hline
\end{tabular}

With the current pressure of the reservoir with 1567 psia, one considers $\mathrm{Z}$ with 0.855 ; there is the gas formation volume factor $\left(\mathrm{B}_{\mathrm{g}}\right)$ which is equal to $0.00172 \mathrm{rb} / \mathrm{scf}$ and the factor of the expansion of the gas (E) to $581.4 \mathrm{scf} / \mathrm{rb}$ and $103.5 \mathrm{scf} / \mathrm{rcf}$. One thus notices the significant reduction in the gas expansion dissolved in the oil of the reservoir a significant production of dissolved gas.

\section{iv. Calculations of Various Volumes of Gas and Oil}

Our reservoir of study being a gas cap reservoir and the pressure of the reservoir is strictly inferior than the pressure of bubble point thus the material balance equation will be based on an oil reservoir with a gas cap and one supposes that the water entry is equal to zero. This equation is given in the form $[10,6]$ :

$$
\mathrm{N}_{\mathrm{p}}\left(\mathrm{B}_{\mathrm{o}}+\left(\mathrm{R}_{\mathrm{p}}-\mathrm{R}_{\mathrm{s}}\right) \mathrm{B}_{\mathrm{g}}\right)=\mathrm{NB}_{\mathrm{oi}}\left[\frac{\left(B_{o}-B_{o i}\right)+\left(R_{S i}-R_{S}\right) B_{g}}{B_{o i}}+m\left(\frac{B_{g}}{B_{g i}}-1\right)\right]
$$

The equation (12) can be reduced in the form of a linear equation:

$$
\mathrm{F}=\mathrm{N}\left(\mathrm{E}_{\mathrm{o}}+\mathrm{mE} \mathrm{E}_{\mathrm{g}}\right)
$$

with $\mathrm{F}$ : production or volume of the fluids extracted in the reservoir ; $\mathrm{E}_{\mathrm{o}}$ : volume or expansion of oil and gas in solution; $\mathrm{m}$ : ratio of the volume of gas of the gas cap on the volume of oil; $\mathrm{E}_{\mathrm{g}}$ : volume or expansion of gas of the gas cap which is defined as follows:

$$
\mathrm{E}_{\mathrm{g}}=B_{o i}\left[\frac{B_{g}}{B_{g i}}-1\right]
$$

For a reservoir saturated with oil with the constant volume of the pores, one will find the volume of gas produced on the surface $\left(G_{p}\right)$ by this equation:

$$
\mathrm{G}_{\mathrm{p}}=\mathrm{NR}_{\mathrm{si}^{-}}\left[\left(N-N_{p}\right) R_{s}+\frac{N B_{o i}-\left(N-N_{p}\right) B_{o}}{B_{g}}\right]
$$

with $\mathrm{NR}_{\text {si: }}$ initial quantity of gas dissolved in oil; $(N-$ $\left.N_{p}\right) R_{s}$ : produced quantity of gas dissolved in oil and $\frac{N B_{o i}-\left(N-N_{p}\right) B_{O}}{B_{g}}$ : the free gas.

On this, one has the equation:

$$
\mathrm{Rp}=\frac{G_{p}}{N_{p}}
$$

who is the ratio of cumulative production of gas on oil.

According to parameters PVT (gas-oil in solution ratio $\left(\mathrm{R}_{\mathrm{s}}\right)$, gas formation volume factor volume factor $\left(\mathrm{B}_{\mathrm{g}}\right)$ and oil formation volume factor volume factor $\left(B_{0}\right)$ ) of the various pressures of Upper Pinda reservoir of the Libwa field, we can determine the volume of cumulative gas production $\left(\mathrm{G}_{\mathrm{p}}\right)$, the quantity of the Cumulative oil production $\left(\mathrm{N}_{\mathrm{p}}\right)$ starting from the factor of recovery $F_{R}$, and the cumulative ratio of production $\left(\mathrm{R}_{\mathrm{P}}\right)$ (Table 6).

Table 6. Determination of volumes of the fluids produced according to the evolution of the pressure of the Upper Pinda reservoir in the Libwa field.

\begin{tabular}{llllllll}
\hline \multirow{2}{*}{ Pression (psia) } & Rs & Bo & Bg & $\mathbf{F}_{\mathbf{R}}$ & Np & Gp & Rp \\
\cline { 2 - 7 } & $\mathbf{( s c f / s t b )}$ & $\mathbf{( r b / \mathbf { s t b } )}$ & $\mathbf{( r b / \mathbf { s c f } )}$ & $\mathbf{( \% )}$ & $\mathbf{( S t b )}$ & $\mathbf{( B S c f )}$ & $\mathbf{( S c f / \text { Stb) }}$ \\
\hline 2670 & 550 & 1.238 & 0.00101 & & & & \\
2583 & 550 & 1.31 & 0.00103 & & & & \\
2500 & 532 & 1.303 & 0.00106 & & & & \\
2300 & 485 & 1.279 & 0.00116 & 1.67 & 8199700 & 44.205 & 5391.086 \\
2100 & 441 & 1.256 & 0.00127 & 2.1 & 10311000 & 54.827 & 5317.416 \\
1900 & 398 & 1.234 & 0.00141 & 2.58 & 12667800 & 67.194 & 5304.339 \\
1700 & 357 & 1.213 & 0.00159 & 3.11 & 15270100 & 80.844 & 5294.323 \\
1500 & 318 & 1.194 & 0.00183 & 3.7 & 18167000 & 96.03 & 5285.981 \\
1300 & 281 & 1.176 & 0.00214 & 4.3 & 21113000 & 112.184 & 5313.515 \\
1100 & 246 & 1.159 & 0.00257 & 4.97 & 24402700 & 129.169 & 5293.231 \\
900 & 213 & 1.144 & 0.0032 & 5.65 & 27741500 & 147.035 & 5300.19 \\
700 & 181 & 1.129 & 0.00419 & 6.36 & 31227600 & 165.644 & 5304.405 \\
\hline
\end{tabular}

From table 5, we can trace the material balance an equation of a straight line (10) to find $\mathrm{m}$. Knowing that the volume of oil initiallyt in place $(\mathrm{N})$ is known, the linear equation (10) becomes [3]:

$$
\left(\frac{F}{N}-E_{o}\right)=m E_{g}
$$

One regards $m$ as the slope of the equation (13). One has figure 3 below. 


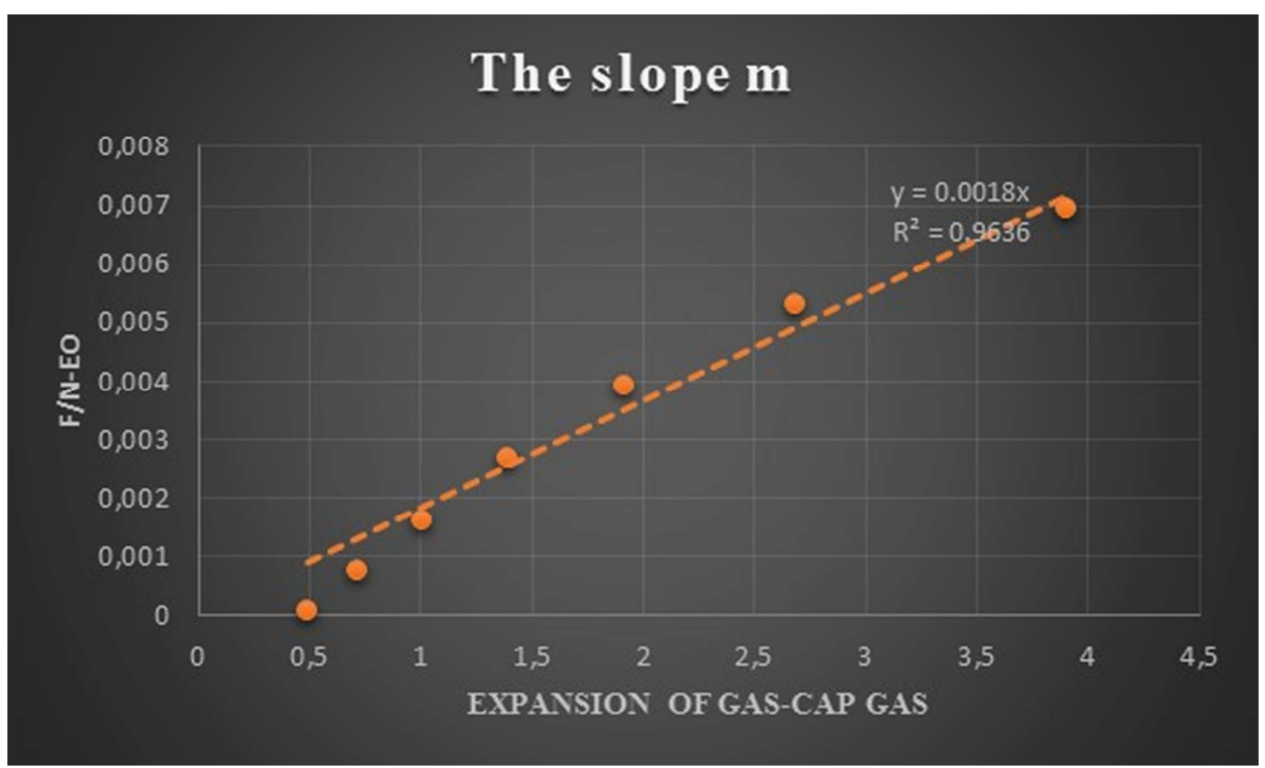

Figure 3. Gas-cap factor or slope $(\mathrm{m})$.

One obtains the factor of the gas cap " $\mathrm{m}$ " compared to the volume of oil starting from figure 3 who is equal to 0,0018 and one remark that this value of $m$ is strictly inferior than 1 , this conduct us to say that the oilfield of the Upper Pinda reservoir behaves like an oilfield with dissolved gas, not of maintenance of $\mathrm{P}$ and one has a release of the GOR, this was proven in 2009 by the different ratios of production of this field. This value of $\mathrm{m}$ can help us to find the expansion of the primary gas cap some using the following equation:

$$
\mathrm{m}=\frac{G B_{g i}}{N B_{o i}}
$$

some drawstring $\mathrm{G}$ initial volume from gas of the gas cap in the equation (14), one has:

$$
\mathrm{G}=\mathrm{m} \frac{N B_{o i}}{B_{g i}}
$$

Some replacing each parameter by his value in the equation (16), one has $\mathrm{G}$ who is worth 1083.3112 MMscf in the conditions of surface and the basic conditions, one has the expansion of the primary gas cap $G$ under form of this equation:

$$
\mathrm{G}=\mathrm{mNBoi}
$$

who is equal to 1.09414 MMscf.

\subsection{Determination of the New Gas Cap in the Libwa Field}

As the pressure of the Upper Pinda reservoir in the Libwa field has dropped until the pressure of $1567 \mathrm{psia}$, the expansion of the gas cap, expressed in volume at the pressure P (1567), is written:

$$
\mathrm{E}_{\mathrm{g}}=\mathrm{mNBoi}\left(\frac{B_{g}}{B_{g i}}-1\right)
$$

one has $\mathrm{E}_{\mathrm{g}}$ equal to $0.76915 \mathrm{MMscf}$. Some supposing that there was not the production of gas starting from the gas-cap during the pressure drop, new volume $\left(G^{\prime}\right)$ new volume $\left(G^{\prime}\right)$ can be given as follows: Volume of gas to the pressure $\mathrm{P}$ (1567 psia):

$$
\mathrm{G}^{\prime}=\mathrm{G}^{*} \mathrm{~B}_{\mathrm{g}}
$$

or

$$
\mathrm{G}^{\prime}=\mathrm{E}_{\mathrm{g}}+\mathrm{G}^{*} \mathrm{~B}_{\mathrm{gi}}
$$

Some replacing each parameter by his value in the equation (20), one has $\mathrm{G}^{\prime}$ who is worth 1,8633 MMscf in the basic conditions. Within to the different ratios of production and and studies undertaken in the Libwa field, one estimates that there was a cumulative production of 227.7 MMstb since 1990 up to 2018. One uses this history of production of the Libwa field to find the quantity of remaining oil $\left(\mathrm{N}_{\mathrm{R}}\right)$, the latter is given in the form of this equation:

$$
\mathrm{N}_{\mathrm{R}}=\left(\mathrm{N}-\mathrm{N}_{\mathrm{p}}\right) \text { Bo }
$$

by replacing each parameter by his value in the equation (21), there is $\mathrm{N}_{\mathrm{R}}$ who is worth $314.38 \mathrm{MMstb}$ under the basic conditions. In this case, we can determine the impact of the new gas cap on the quantity of remaining oil in the Libwa field of the Pinda reservoir starting from the value of gas cap the factor current $(\mathrm{m})$ given in the form:

$$
\mathrm{m}=\frac{V_{g c}}{V_{o i l}}
$$

his gives us $\mathrm{m}$ which is worth 0.0059 . In spite of the release of gas dissolved towards the primary gas cap for the period of production going from 1990 to 2018 , we understand that there is not always the maintenance of pressure in the oilfield starting from the secondary gas cap.

\section{Conclusion}

During the oil production in the Libwa field, the pressure 
of the Upper Pinda reservoir had dropped i.e. the mechanism of main drainage to dissolved gas used in this reservoir did not maintain almost any more the pressure of the reservoir above or equal to the pressure of the bubble points. Thus, during this drop pressure of 2670 psia with 1567 psia, there was release of gas dissolved in the reservoir of which a part was produced on the surface and another had trapped itself with the top of the reservoir. Just as one could observe an abrupt fall of the average production of the oil field Libwa of 14.7 MMstb in 2009 to 0.233 MMstb in 2018. While seeking to improve the recuperation of oil of this field, it was necessary to estimate firstly the quantity of gas in released and trapped solution with the top of this reservoir while knowing that according to studies' undertaken previously in the Upper Pinda reservoir of the oil field Libwa, it was announced the presence of a gas-cap. But, it was noticed that this gas cap does not have compensated for the energy produced on the surface during the drop pressure in the reservoir. Thus we proceeded starting from this study to really estimate the quantity of gas of the primary gas cap which gave us a value to the order of 1.09414 MMscf under the basic conditions and the factor of the primary gas cap (m) with 0.0018 who is almost null. This value of the factor of the primary gas cap shows that the primary gas cap was too weak to maintain the pressure of the reservoir. This conduct to a new study by taking account of the gas expansion in the gas cap. Thus, we determined the quantity of gas in the new gas cap to $1.86329 \mathrm{MMscf}$ under the basic conditions. And, by also considering the quantity of remaining oil in the reservoir according to the basic conditions, the new factor of the gas cap $(\mathrm{m})$ is worth 0.0059 . This second result always shows the insufficiency of the new gas cap to maintain even partially the pressure of the Upper Pinda reservoir in the Libwa field. To optimize the production in this field, we recommend to the company in place to make the injection of gas to the top of its reservoir in order to equalize the pressure of the reservoir to that of the bubble points. To arrive there, it is necessary necessarily that the ratio of the volume of gas of the gas cap on the volume of remaining oil in the reservoir is at least equal to value 10 to completely replace the mechanism of drainage in the Upper Pinda reservoir in the Libwa field.

\section{Acknowledgements}

We would like to thank the oil company PERENCO DRC for making the data used in this study available to us.

\title{
Nomenclature
}

$\begin{array}{ll}\mathrm{B}_{\mathrm{g}} & \text { Gas formation volume factor } \\ \mathrm{B}_{\mathrm{gi}} & \text { Initial gas formation volume factor } \\ \mathrm{B}_{\mathrm{o}} & \text { Oil formation volume factor } \\ \mathrm{B}_{\mathrm{oi}} & \text { Initial oil formation volume factor } \\ \mathrm{E} & \text { Factor to the gas expansion } \\ \mathrm{E}_{\mathrm{g}} & \text { Expansion of the gas-cap gas } \\ \mathrm{E}_{\mathrm{o}} & \text { Term in the material balance equation accounting for the expansion of the oil and its originally dissolved gas } \\ \mathrm{F} & \text { Production term in the material balance equation } \\ \mathrm{G}_{\mathrm{p}} & \text { Cumulative gas production } \\ \mathrm{G} & \text { Gas of gas-cap initially in place } \\ \mathrm{G} & \text { New volume of gas in gas-cap } \\ \mathrm{Kh} & \text { Permeability horizontal } \\ \mathrm{m} & \text { Gas-cap factor or slope for material balance an equation of a straight line } \\ \mathrm{N} & \text { Stock tank oil initially in place (STOIIP) } \\ \mathrm{N}_{\mathrm{p}} & \text { Cumulative oil production } \\ \mathrm{N}_{\mathrm{R}} & \text { Volume of oil remaining in the reservoir } \\ \mathrm{R}_{\mathrm{p}} & \text { Cumulative gas oil ratio } \\ \mathrm{R}_{\mathrm{s}} & \text { Solution (or dissolved) gas oil ratio } \\ \mathrm{R}_{\mathrm{si}} & \text { Initial solution gas oil ratio } \\ \mathrm{Z} & \text { Gas deviation factor } \\ \mathrm{Z}_{\mathrm{sc}} & \text { Gas deviation factor at standard conditions } \\ & \end{array}$

\author{
Abbreviations \\ ${ }^{\circ}$ API Degree American petroleum institute \\ Ave $S_{w} \quad$ Average water saturation \\ Ave perm Average permeability \\ $\mathrm{C}_{\mathrm{p}} \quad$ Centipoise \\ D Depth \\ dD Difference in depth
}




$\begin{array}{ll}\mathrm{dP} & \text { Difference in pression } \\ \mathrm{DST} & \text { Drill Stream Test } \\ \mathrm{F} & \text { Farenheit } \\ \mathrm{F}_{\mathrm{R}} & \text { Oil recuperation factor } \\ \mathrm{ft} & \text { Feet } \\ \mathrm{GOC} & \text { Gas-oil contact } \\ \mathrm{GOR} & \text { Gas-oil ratio } \\ \mathrm{Km} & \text { Kilometer } \\ \mathrm{mD} & \text { milliDarcy } \\ \mathrm{MMscf} & \text { Millions standard cubic feet } \\ \mathrm{MMstb} & \text { Millions standard tank barrel } \\ \mathrm{OWC} & \text { Oil-water contact } \\ \mathrm{P}_{\mathrm{b}} & \text { Bubble point pressure } \\ \mathrm{P}_{\mathrm{o}} & \text { Oil pressure } \\ \mathrm{P}_{\mathrm{g}} & \text { Gas pressure } \\ \mathrm{P}_{\mathrm{sc}} & \text { Pressure at standard conditions } \\ \mathrm{Psia} & \text { Pounds per square inch atmospheric } \\ \mathrm{psi} & \text { square inch per pound } \\ \mathrm{P}_{\mathrm{w}} & \text { water pressure } \\ \mathrm{PVT} & \text { Pression, Volume and Temperature } \\ \mathrm{Scf} & \text { Standard cubic feet } \\ \mathrm{Stb} & \text { Standard tank barrel } \\ \mathrm{rb} & \text { Reference barrel } \\ \mathrm{T}_{\mathrm{sc}} & \text { Temperature at standard conditions } \\ \mathrm{UP} & \text { Upper Pinda } \\ & \end{array}$

\section{References}

[1] Pierre Donnez, "Essentials of Reservoir engineering", Editions Technip; volume 2, 512 pp, 2006.

[2] Joel Kabesa Kilungu, Dominique Wetshondo O, et al, "Estimation of the Performance and Prediction of the Decline Time of Reservoir: A Case study of Libwa field, Democratic Republic of Congo", Volume 5, Issue 6, June - 2019, International Journal of Advances in Scientific Research and Engineering IJASRE-33237, 58-69 pp.

[3] Tarek Ahmed, "Reservoir engineering hand book", second edition, Gulf Professional Publishing, 1188 pp, 2001.

[4] C. SALLE, J. DEBYSER, "Formation of the oilfield: Study of the fundamental geological phenomenon", Editions TechnipParis, 237pp, 1976.

[5] René Cossé, "The oilfield", Editions Technip-Paris, 325 pp, 1988.

[6] NNAEMEKA EZEKWE, "Petroleum Reservoir Engineering Practice", Library of Congress Cataloging-in-Publication Data, 801pp, 2010.

[7] LP. DAKE, "Fundamentals of reservoir engineering", ELSEVIER, Developments in Petroleum Science, 8, 498pp, 1978.

[8] Chapman, R. E, "Petroleum Geology, a Concise Study". Elsevier Scientific Publishing Co., Amsterdam, 67-76 pp, 1973.

[9] BOYUN GUO, William C. Lyons, Ali Ghalambor, "Petroleum Production Engineering: a computer-assisted approach", Elsevier Science \& Technology Books, 287 pp, February 2007.

[10] Martin J. Blunt, "Reservoir Performance Predictors", Master of Science in Petroleum Engineering Centre for Petroleum Studies, Department of Earth Science and Engineering, Imperial College London, 307 pp, January 2012. 